\title{
Designing a Sustainable World Class Manufacturing Model in the Automotive Industry in Iran
}

\author{
Zahra Pourvaziry*, Gholamreza Hashemzadeh Khorasgani, Mahmud Modiri, Hassan Farsijani
}

\begin{abstract}
This study is functional in terms of purpose and descriptive-exploratory in terms of doing research. The method of data collection is library and field studies using a questionnaire tool. Those with relevant postgraduate qualifications and at least ten years of working experience, especially management experience in the automotive industry with a sufficiently motivated executive background to participate were chosen. In the quantitative section, the experts include nine executives and senior experts in the automotive industry who were selected through snowballing. The most important dimensions and criteria of a sustainable world class manufacturing model are identified by a theoretical literature review and interviews with the experts, and they were then screened and localized with expert opinions and fuzzy Delphi techniques. After collecting data through a paired comparisons questionnaire, the data were analyzed by using a fuzzy-dimensional network analysis process hybrid technique. The findings of fuzzy DEMATEL indicated that the dimensions of "environmental", "economic" and "social" sustainability help in achieving sustainable world class manufacturing.
\end{abstract}

Keywords: automotive industry; fuzzy Delphi techniques; fuzzy DEMATEL technique; fuzzy network analysis process; sustainable manufacturing; world class

\section{INTRODUCTION}

The concept of globalization requires manufacturing companies to strive to manufacture sustainable products with re-engineered technologies, thereby enhancing their competitive advantage in the current market [1]. In this respect, practicing to move along the path of sustainable manufacturing is in fact the hope to achieve profitability, flexibility and positive social and environmental impacts simultaneously. A model of strategic actions for sustainable production can be provided through pure thinking to successfully use sustainable business results. Professional organizations at world-class levels can help empower this path and address barriers through targeted interventions [1]. The concept of sustainable manufacturing emerged at the United Nations Conference on Environment and Development in 1992 and it relates to the concept of sustainable development. It was concluded at the conference that the main cause of the global environmental decline, especially in industrialized countries, is the unstable pattern of manufacturing and consumption. Sustainable manufacturing can be defined as (1) creating goods and services through non-contaminated processes and systems, (2) conservation of energy and natural resources, (3) performing economic and sustainable operations, (4) maintaining a safe and healthy environment for employees, communities, and consumers, and (5) a creative and social reward for employees [32].

Developed countries and world-class organizations are required to implement tangible sustainable development information and awareness in all aspects of people's lives by designing sustainable models [11]. In the industry sector, the focus of sustainable development is on creating projects that can ensure the interaction between the short-term goals of the project and the long-term goals of operating systems while preserving natural resources, the environment and human needs. In this process, optimal utilization of a variety of resources is considered as the main decision-making axis [2].

Implementing sustainable consumption and manufacturing helps reduce future economic, environmental and social costs, while it simultaneously fosters economic competitiveness and reduces poverty, increases productivity, reduces pollution throughout the life cycle and enhances life quality. As such, companies, especially large and transnational corporations, are encouraged to adopt sustainable practices and incorporate sustainable information into their reporting cycle because it is anticipated that by 2030, sustainable practices will be included in the National Priorities Program [11]. The increased demand for sustainable products and services drives the organization to accept innovative concepts that directly affect the life cycle and it causes the organization to move forward in that direction. In the modern era, particular attention is paid in to the manufacturing systems that simultaneously integrate products and services, reduce environmental impacts and create business opportunities for industry, while simultaneously taking into account the social dimensions [3].

Moving towards sustainability makes all organizations and industries more aware of consumption patterns, and companies take responsibility for product life cycle issues. Reaching the highest levels of sustainability is possible when future research focuses on all aspects of the models designed in this area [4]. Indeed, in the concept of sustainability, the goal is to design and understand the concept of sustainable value based on the three key elements of the product, service and system, while simultaneously examining the economic, environmental and social value of each and the type of interaction required for each dimension [3]. The policies adopted for sustainable development are qualitative and realistic, with sufficient information and measurable criteria available for the environmental, social and economic status. Explaining and formulating the criteria that reflect the qualitative characteristics of a society's policies and programs in various economic, social, environmental and other areas in the form of quantifiable and evaluable data is always one of the most important issues and concerns of decision makers, observers and researchers [2].

Iran, along with many other countries, recognized the importance of this and considered the issue of sustainable development as an influential element in the country's political and economic strategies and sought to broaden the focus on achieving sustainable development goals across all 
arenas. On the other hand, despite close political, cultural and social relations with some neighboring countries, Iran is expected to achieve greater added value and gain a lucrative economic opportunity by identifying and gaining customer expectations in overseas markets and producing high-quality products for sustainable world class manufacturing. In this regard, the automotive company has started operations and exported products to some countries. However, issues and problems such as competitors' high quality products, long service time, poor flexibility in products and services, competitive pricing issues and rising costs, and most importantly, low product innovation have made the industry fail to achieve the expected sustainable competitive advantage. In fact, the development and use of up-to-date technologies is a problem that most of all requires the automotive industry to communicate with the international environment. However, the sanctions also damaged the infrastructure of the industry, and the US exit from the JCPOA, and then the exit of international partners, changed the development plans of domestic companies. Thus, the existence of such issues led a suitable sustainable world class manufacturing model to be presented in the automotive industry in Iran to reach the target markets through export potential and competitive advantage, which can create costeffective regional export capability.

The questions raised in this study are: What are the dimensions and criteria of a suitable sustainable world-class manufacturing model in the automotive industry in Iran? What is the relationship between the dimensions and criteria? What is the importance of each dimension of the sustainable world class manufacturing?

By defining the dimensions and criteria of the sustainable world-class manufacturing model via the fuzzy Delphi method, the fuzzy DEMATEL technique is used in this study to determine the communications and mutual impact, and the combinational technique of the fuzzy DEMATEL-based network analysis process is used to determine its importance.

\section{THEORETICAL FOUNDATIONS AND LITERATURE REVIEW}

\subsection{World Class Manufacturing}

World Class Manufacturing (WCM) is an applied program system that combines the best practices that are compatible with one another so that businesses can continue to operate systematically. WCM is a dynamic model that is evolving and renovating. WCM performance monitoring is also followed by this change [18]. The concept of WCM is a critical process. This proposes a new way to achieve a global status [19]. In today's dynamic and complex environment, organizations and industries compete internationally, and world-class manufacturing of a product is an important element of successful global competition.

Schoenberger was the first to introduce the concept of WCM as follows: it is an extensive agreement on the continuous improvement of quality, cost, waiting time and customer service. He described flexibility as the primary goal of the WCM system. As a result, WCM is at the level of organizational performance that makes possible the ability to compete globally and can respond appropriately to today's business needs [5].

Green [34] provided a more comprehensive definition and said that global benchmarking organizations are the ones which perform best in the world class of related industries. Namely, they are in close contact with their customers and suppliers and are aware of their competitors' performance and they recognize their weaknesses and strengths.

What researchers have in common is that, philosophically, an organization achieves the WCM status when it is able to successfully create productivity capabilities to support the entire organization in achieving a sustainable competitive advantage in the areas of cost, quality, delivery, flexibility, innovation and customer service [6]. The concept of a seven-dimensional WCM can lead to concurrent competitive achievements that can be identified through applying strategies based on the same potentials. WCM is a systematic approach that can manage the criteria for realizing the organization's future progress. In fact, the constant increase in competition makes it possible for each company to review its production processes. There are many different techniques and methods in this path. One of the best optimization techniques is WCM. WCM implementation is a promising issue because it creates a performance measurement system based on the core competencies of organizations which identifies the relationships between the critical factors. Its final output is a good performance measure to help managers make decisions [7].

WCM is a comprehensive term for common methods and effective techniques for delivering desirable high-quality products, timely delivery at full order price and low cost products. Companies dependent on global classification strategies focus on improving operations. This often increases productivity. The WCM framework is based on the effective improvement of quality, cost, delivery and flexibility, which takes time to reach this level [8]. In fact, WCM creates a new paradigm that is rapidly evolving according to the customer needs, and it can guide the organization towards excellence with much flexibility through providing novel and specific solutions with the rapid changes that take place in the markets according to the preferences and volume of production.

\subsection{Sustainability}

The concept of sustainable production emerged at the United Nations Conference on Environment and Development in 1992 and it is concerned with the concept of sustainable development. It was concluded in the conference that the main cause of the global environmental decline, especially in industrialized countries, is the unstable pattern of manufacturing and consumption. Sustainable manufacturing can be defined as creating goods and services through non-contaminated processes and systems, conservation of energy and natural resources, performing economic and sustainable operations, maintaining safe and healthy environment for employees, communities and consumers and a creative and social reward for employees [5]. On September 17, 2015, the sustainable development 
goals of the 2030 Program were adopted and implemented from January 2016. They take common global efforts to achieve a sustainable world for all with regard to poverty, inequality, climate change, environmental degradation, welfare, peace and justice on the forefront of all organizations' affairs. Sustainability in manufacturing and service attracted the attention of many business professionals, and several research projects and many related documents were published. Indeed, the sustainability theory and practices in manufacturing became a vital issue in the dynamic business development [9]. When sustainability is done successfully, a new strategy approach in order to increase the efficiency and effectiveness in organizational performance is offered [10].

A definition of sustainable development and sustainability that can be agreed upon by the majority encompasses the three main areas of economic, environmental and social development, and the features in each of these sectors are examined [13].

The economic perspective is one of the dimensions of the sustainable development model. Sustainable development is one of the future paths of economic development for each country [11]. A sustainable economic system is able to produce goods or services that reduce the external debt of the government and prevent the imbalance between the various economic sectors while simultaneously protecting the agricultural and industrial production from any damage [6].

Another perspective is the environmental perspective. In general, companies and the environment consistently became two opposing aspects, with any business activity leading to environmental hazards and environmental concerns perceived as a threat to business expansion. However, this conflict gradually diminished with the development and implementation of sustainable green practices in recent years. Organizations and the environment must work together as a team, while organizations play an important role in exploring and assisting technology solutions to solve environmental issues, while the environment plays an important role in creating occupational opportunities and employment [12]. The last perspective of the sustainable development model is the social perspective. Social sustainability is a cultural system [13]. A sustainable social system should be able to achieve equitable distribution of resources and equality of social facilities and services (such as health, gender equality education, political accountability and participation) [14].

\section{LITERATURE REVIEW}

By surveying sustainable production and consumption in the circular economy, Aravossis [5] explored new concepts of sustainable manufacturing and consumption, and he specifically focused on the economic dimension of sustainability. In the studies of sustainability-based companies focusing on the strategies for greening the workplace, Subbauer \& Schafer showed that human resources in organizations have a key role in improving the products and services and developing environmental innovation. Experimental studies of green initiatives and environmental sustainability for small and medium-sized enterprises [12] also indicated that environmental sustainability is appropriate in terms of green practices, green technology policies, process management and supply chain management. Green technology was mentioned in this study [12]. Vinelli \& Furlan studied the coexistence between progress and innovation in world-class manufacturing. In this study, it was found that to achieve world-class manufacturing, innovation and improvement initiatives should be simultaneously pursued. Therefore, the commitment to continuous improvement and an impediment to innovation were involved in this way. Additionally, Just in Time (JIT) manufacturing has an impact on world-class manufacturing. The study by DeFelice indicated that the constant increase in competition forces each company to examine its production processes in order to minimize costs and maximize customer service. Moreover, the study by Adel Azar [44] indicated that monitoring and controlling, using high efficiency resources, using high efficiency technology and optimizing the production plan to improve productivity are the key indicators of achieving sustainable production in the refineries. Lanndon Ocampo [45] explored the framework of production strategies in the organizational structure by using the sustainability approach, namely the three economic, social and environmental sectors. In addition, OCAMPO [17] proposed and studied the production and sustainable production strategy with the aim of providing comprehensive guidelines for sustainable development decisions by using the fuzzy hierarchical analysis method [29]. Fosso [23] examined the technology foresight for sustainable production in the German auto supplier industry, in which he introduced environmental sustainability as a new production paradigm and stated that environmental sustainability requires the efficient use of resources and energy. Smith \& Ball's research group surveyed the concept of sustainable production in the supply chain to investigate the amount of energy consumed in the supply chain. Winores and Johnson's research group examined the sustainability strategy framework in their model and pointed to market priorities based on this model. The studies by Saloukdar and Seyyed Hosseini [39] pointed to the importance of worldclass manufacturing. The results of their study indicated that many companies do their operations without fully understanding the complexity of the relationships between the areas of the manufacturing strategy. Lack of knowledge or lack of explanation of the relationships among the dispersed elements of production in a unified systematic and causal model and not considering time lag led to a departure from the comprehensive model of the world-class manufacturing competitive advantage. The literature reviews and their criticisms are illustrated in Tab. 1.

Table 1 A summary of literature reviews on sustainable world class manufacturing

\begin{tabular}{|c|l|l|}
\hline \multicolumn{3}{|c}{$[1]$} \\
\hline Researcher & \multicolumn{1}{|c|}{ Research results } & \multicolumn{1}{c|}{ Focused on: } \\
\hline Antonella [7] & $\begin{array}{l}\text { This study explores new } \\
\text { concepts of sustainable } \\
\text { production and } \\
\text { consumption }\end{array}$ & $\begin{array}{l}\text { Focus on the economic } \\
\text { dimension among the } \\
\text { sustainability dimensions }\end{array}$ \\
\hline Stankevi [54] & $\begin{array}{l}\text { Achieving } \\
\text { organizational }\end{array}$ & $\begin{array}{l}\text { Focus on improving the } \\
\text { products and services and }\end{array}$ \\
\hline
\end{tabular}




\begin{tabular}{|c|c|c|}
\hline & $\begin{array}{l}\text { sustainability by } \\
\text { focusing on human } \\
\text { resources as well as } \\
\text { environmental issues in } \\
\text { the production process }\end{array}$ & $\begin{array}{l}\text { on developing } \\
\text { environmental innovation } \\
\text { based on the role of } \\
\text { human resources in } \\
\text { organizations }\end{array}$ \\
\hline Sari [53] & $\begin{array}{l}\text { World-class } \\
\text { manufacturing model } \\
\text { (WCM) and } \\
\text { performance indicators: } \\
\text { a comparison between } \\
\text { WCM firms }\end{array}$ & $\begin{array}{l}\text { Investigation of WCM } \\
\text { Performance and } \\
\text { Production Indicators }\end{array}$ \\
\hline Muhammad [52] & $\begin{array}{l}\text { Production of } \\
\text { sustainable products } \\
\text { based on reengineering } \\
\text { and examining its impact } \\
\text { on the environmental, } \\
\text { economic and social } \\
\text { dimensions }\end{array}$ & $\begin{array}{l}\text { Focus on the } \\
\text { environmental and } \\
\text { economic dimensions }\end{array}$ \\
\hline $\begin{array}{c}\text { Jitesh Thakkar } \\
{[44]}\end{array}$ & $\begin{array}{l}\text { Adoption of green } \\
\text { technology in creating } \\
\text { environmental } \\
\text { sustainability for } \\
\text { manufacturing in SMEs }\end{array}$ & $\begin{array}{l}\text { Focus on the } \\
\text { environmental dimension }\end{array}$ \\
\hline Petrillo [24] & $\begin{array}{l}\text { This research objective } \\
\text { is twofold: First, } \\
\text { providing a "model" to } \\
\text { identify factors that } \\
\text { influence the core } \\
\text { competencies of } \\
\text { organizations. Second, } \\
\text { proposing a } \\
\text { "performance appraisal } \\
\text { system" to establish the } \\
\text { relationship between the } \\
\text { important factors by } \\
\text { using WCM }\end{array}$ & $\begin{array}{l}\text { Studying the } \\
\text { sustainability dimensions } \\
\text { was not the subject of this } \\
\text { article }\end{array}$ \\
\hline Hernández [29] & $\begin{array}{l}\text { General principles of the } \\
\text { WCM }\end{array}$ & Focus on quality \\
\hline Hernández [29] & $\begin{array}{l}\text { Investigating the } \\
\text { components of } \\
\text { organizational strategic } \\
\text { model for achieving } \\
\text { WCM - investigating the } \\
\text { human-economic and } \\
\text { structural components }\end{array}$ & $\begin{array}{l}\text { Studying the } \\
\text { sustainability dimensions } \\
\text { was not the subject of this } \\
\text { article }\end{array}$ \\
\hline Kireitinu [3] & $\begin{array}{l}\text { Focusing on the } \\
\text { production process } \\
\text { strategy roadmap with } \\
\text { the aim of identifying } \\
\text { sustainability and its } \\
\text { associated costs in the } \\
\text { production process }\end{array}$ & $\begin{array}{l}\text { Proposing other } \\
\text { dimensions such as the } \\
\text { economy of culture and } \\
\text { politics as effective } \\
\text { variables - not surveyed }\end{array}$ \\
\hline Adel Azar [5] & $\begin{array}{l}\text { Investigation of the three } \\
\text { dimensions of } \\
\text { sustainability - } \\
\text { (economic, social and } \\
\text { environmental) }\end{array}$ & $\begin{array}{l}\text { Sustainable Production } \\
\text { Indicators }\end{array}$ \\
\hline Fadley et al. [10] & $\begin{array}{l}\text { Investigating the critical } \\
\text { success factors of the } \\
\text { SMP sustainable } \\
\text { manufacturing practices } \\
\text { in the Malaysian } \\
\text { automotive Industry }\end{array}$ & $\begin{array}{l}\text { Investigation of the social } \\
\text { responsibility as the only } \\
\text { factor }\end{array}$ \\
\hline Mirhabibi [5] & $\begin{array}{l}\text { Investigating WCM } \\
\text { components, comparing } \\
\text { conceptual elements of } \\
\text { models }\end{array}$ & $\begin{array}{l}\text { Not reviewing } \\
\text { sustainability dimensions }\end{array}$ \\
\hline $\begin{array}{c}\text { Kireitseu Maxim } \\
{[30]}\end{array}$ & $\begin{array}{l}\text { Examining WCM } \\
\text { dimensions }\end{array}$ & $\begin{array}{l}\text { Production index in } \\
\text { WCM }\end{array}$ \\
\hline $\begin{array}{c}\text { Jain, } \\
\text { Bhurchand[26] }\end{array}$ & $\begin{array}{l}\text { Developing the } \\
\text { dimensions of a WCM } \\
\text { model }\end{array}$ & $\begin{array}{l}\text { Production Indicators in } \\
\text { WCM }\end{array}$ \\
\hline
\end{tabular}

\begin{tabular}{|c|c|c|}
\hline $\begin{array}{c}\text { Andera Chiarini } \\
{[31]}\end{array}$ & WCM indicators & $\begin{array}{l}\text { Increasing productivity by } \\
\text { focusing on new } \\
\text { production standards }\end{array}$ \\
\hline FCA [25] & $\begin{array}{l}\text { A review of the } \\
\text { fundamental concepts of } \\
\text { WCM in the automotive } \\
\text { industry }\end{array}$ & $\begin{array}{l}\text { Not reviewing } \\
\text { sustainability dimensions }\end{array}$ \\
\hline OCAMPO [17] & $\begin{array}{l}\text { Introducing the three } \\
\text { dimensions of the } \\
\text { economic, social and } \\
\text { environmental } \\
\text { sustainability }\end{array}$ & $\begin{array}{l}\text { Investigation of the } \\
\text { quantitative dimensions of } \\
\text { stability }\end{array}$ \\
\hline OCAMPO [17] & $\begin{array}{l}\text { Reviewing sustainable } \\
\text { production strategies }\end{array}$ & $\begin{array}{l}\text { Not reviewing } \\
\text { sustainability dimensions }\end{array}$ \\
\hline Fösso [33] & $\begin{array}{l}\text { Technology forecasting } \\
\text { being pivotal to } \\
\text { sustainable production in } \\
\text { the German automotive } \\
\text { supplying industry - the } \\
\text { importance of the } \\
\text { environmental } \\
\text { dimension }\end{array}$ & $\begin{array}{l}\text { Considering the } \\
\text { environmental dimension } \\
\text { of sustainability as the } \\
\text { only dimension }\end{array}$ \\
\hline Sarkar [35] & $\begin{array}{l}\text { The Impact of } \\
\text { WCM Methods on } \\
\text { Corporate Performance }\end{array}$ & $\begin{array}{l}\text { Focusing on } \\
\text { WCM dimensions }\end{array}$ \\
\hline Atkinson [20] & $\begin{array}{l}\text { A comprehensive look at } \\
\text { the sustainable } \\
\text { production framework in } \\
\text { the organization }\end{array}$ & $\begin{array}{l}\text { Not reviewing } \\
\text { sustainability dimensions }\end{array}$ \\
\hline $\begin{array}{c}\text { AndreaFurlan } \\
{[16]}\end{array}$ & $\begin{array}{l}\text { Identifying the Factors } \\
\text { Affecting the } \\
\text { Implementation of } \\
\text { WCM Techniques in the } \\
\text { Oil Industry }\end{array}$ & WCM \\
\hline Farsijani [5] & $\begin{array}{l}\text { Examining } \\
\text { WCM indicators }\end{array}$ & Production Indicators \\
\hline $\begin{array}{l}\text { Heleem et al. } \\
{[48]}\end{array}$ & WCM factors & WCM \\
\hline $\begin{array}{l}\text { Heleem et al. } \\
{[48]}\end{array}$ & $\begin{array}{l}\text { Dimensions of success } \\
\text { in WCM }\end{array}$ & WCM \\
\hline
\end{tabular}

\section{RESEARCH GAP}

Undoubtedly, there were many studies on the concepts of sustainability and production in WCM, separately based on literature reviews. However, given the importance of criteria taken from environmental indicators, previous studies were conducted by focusing on this environmental component sector. Additionally, as the world becomes more competitive today, the economic index has a very special place in the models under consideration. The distinguishing feature of the present study is the simultaneous consideration of three sustainability indicators, namely the social, economic, and environmental indicators, which are less common in the studies on WCM.

In the present study, the indicators identified from the literature review are presented and analyzed in Tab. 2. These indicators are identified in the area of sustainability.

Fuzzy DEMATEL is a structural model used to analyze the causal relationship between complex factors. The DEMATEL technique can create a structural map of the system based on the causal relationship [50]. In fact, DEMATEL is a mathematical approach that can be used to analyze the causal dependence and relationship between the dimensions of a problem for complex management and efficient problem solving, and the end result of the 
DEMATEL process is a visual demonstration that relies on the graph theory [48]. The ANP process creates complex interdependencies between decision levels and evaluation factors. The level of decision making can be directly or indirectly overcome and influenced by other decision factors and levels using ANP. In the ANP model, human judgments are integrated to compare two factors (sub-factors). Uncertainty in the judgment of decision makers compared to binary factors is significantly reduced. Therefore, the fuzzy ANP method for handling relative uncertainty relative to definitive values emerged [49].

Table 2 Identified indicators in the field of effective sustainability in WCM

\begin{tabular}{|c|l|c|}
\hline Dimension & \multicolumn{1}{|c|}{ Criteria } & References \\
\hline \multirow{5}{*}{ Economic } & Employment & Kucerova [27] \\
\cline { 2 - 3 } & Innovation & Muhammad [52] \\
\cline { 2 - 3 } & Operational costs & Nurul [10] \\
\cline { 2 - 3 } & Efficiency & Lanndon [46] \\
\cline { 2 - 3 } & Financial health & Qi, X. [19] \\
\hline \multirow{5}{*}{ Social } & Participating in social events & Peterson, N. D. [14] \\
\cline { 2 - 3 } & Employee satisfaction & Nurul Fadly [10] \\
\cline { 2 - 3 } & Empowering Human Capital & Peterson, N. D. [14] \\
\cline { 2 - 3 } & $\begin{array}{l}\text { Respecting civil laws and } \\
\text { regulations }\end{array}$ & Yoo, C. [28] \\
\cline { 2 - 3 } & Community Health & Kucerova [27] \\
\cline { 2 - 3 } & Customer satisfaction & Lanndon [46] \\
\hline & Environmental pollutants & Moultrie, J. [9] \\
\cline { 2 - 3 } & $\begin{array}{l}\text { Conservation of natural } \\
\text { resources }\end{array}$ & Yacob [12] \\
\cline { 2 - 3 } & $\begin{array}{l}\text { Use of recyclable raw } \\
\text { materials }\end{array}$ & Lanndon [46] \\
\cline { 2 - 3 } & Using organic raw materials & Yoo, C. [28] \\
\cline { 2 - 3 } & Responsiveness & Atkinson [20] \\
\cline { 2 - 3 } & Energy & \\
\hline
\end{tabular}

\section{METHODOLOGY}

The present study is applied in terms of purpose and it is descriptive-exploratory in terms of doing the research. The data collection method is library studies and is field one. Data collection tool is a researcher-made questionnaire and interviews with experts. The content validity of the questionnaire was assessed through expert opinions. The expert's research community consists of $22 \mathrm{WCM}$ experts, managers and professionals in the field, as well as of university professors. Those with relevant postgraduate qualifications (world class and sustainable development) and at least ten years of working experience, especially management experience in the automotive industry with a sufficiently motivated executive background to participate were chosen. The most important point in determining the experts is the presence of academic experts against professional and empirical experts in order to ensure the consistency of using different perspectives in this research. In the qualitative section, the most important dimensions and criteria of sustainable WCM were identified and partially screened and localized by the fuzzy Delphi method through theoretical literature review and interviews with the experts in which the experts expressed their views on the dimensions and criteria of sustainability of which some were merged, eliminated, added or modified. Moreover, the fuzzy DEMATEL method was used to determine the relationships and the impact of sustainability dimensions and criteria, and the ANP method was used to determine the importance of each dimension and the criteria of sustainability affecting WCM; whereas the ANP method was used with regard to the intrinsic relationship identified by the DANP method between the dimensions and criteria of sustainability. In the study of Lin and Cheng [51], the method was used to solve the fuzzy Delphi problem and the fuzzy DANP problem. The steps of the problem-solving method are listed in the reference section.

Table 3 Screening and survey results of the sustainability criteria affecting the WCM by the fuzzy Delphi method

\begin{tabular}{|c|c|c|c|c|c|}
\hline 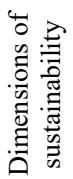 & Row & $\begin{array}{c}\text { Sustainability } \\
\text { Criteria }\end{array}$ & $\begin{array}{l}\text { Non-fuzz } \\
\text { average } \\
\text { of expert } \\
\text { opinions }\end{array}$ & $\begin{array}{c}\text { Questionnaire } \\
\text { mean } \\
\text { differences }\end{array}$ & Result \\
\hline \multirow{5}{*}{ 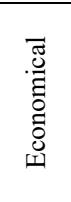 } & 1 & Employment & 8.08 & 0.17 & Accepted \\
\hline & 2 & Innovation & 8.17 & 0.18 & Accepted \\
\hline & 3 & $\begin{array}{l}\text { Operational } \\
\text { cost }\end{array}$ & 8.25 & 0.17 & Accepted \\
\hline & 4 & Efficiency & 8.16 & 0.09 & Accepted \\
\hline & 5 & Financial health & 8.41 & 0.17 & Accepted \\
\hline \multirow{6}{*}{  } & 6 & $\begin{array}{l}\text { Participating in } \\
\text { social events }\end{array}$ & 4.55 & 0.01 & Rejected \\
\hline & 7 & $\begin{array}{l}\text { Employee } \\
\text { satisfaction }\end{array}$ & 8.33 & 0.17 & Accepted \\
\hline & 8 & $\begin{array}{l}\text { Empowering } \\
\text { human capital }\end{array}$ & 8.33 & 0.17 & Accepted \\
\hline & 9 & $\begin{array}{l}\text { Respecting civil } \\
\text { laws and } \\
\text { regulations }\end{array}$ & 8.49 & 0.17 & Accepted \\
\hline & 10 & $\begin{array}{l}\text { Community } \\
\text { health }\end{array}$ & 8.00 & 0.18 & Accepted \\
\hline & 11 & $\begin{array}{l}\text { Customer } \\
\text { satisfaction }\end{array}$ & 8.00 & 0.18 & Accepted \\
\hline \multirow{5}{*}{$\begin{array}{l}\overline{0} \\
.00 \\
00 \\
0 \\
0\end{array}$} & 12 & $\begin{array}{l}\text { Reducing } \\
\text { environmental } \\
\text { pollutants } \\
\end{array}$ & 8.17 & 0.09 & Accepted \\
\hline & 13 & $\begin{array}{l}\text { Conservation of } \\
\text { natural } \\
\text { resources }\end{array}$ & 8.08 & 0.17 & Accepted \\
\hline & 14 & $\begin{array}{l}\text { Using } \\
\text { recyclable raw } \\
\text { materials }\end{array}$ & 8.41 & 0.17 & Accepted \\
\hline & 16 & Responsiveness & 8.33 & 0.17 & Accepted \\
\hline & 17 & Energy & 8.33 & 0.17 & Accepted \\
\hline
\end{tabular}

\section{DATA ANALYSIS}

In this study, the dimensions and criteria of sustainability affecting a sustainable WCM were identified by a theoretical review of literature and various articles, as well as interviews with the experts. Furthermore, localization and screening were performed by using the fuzzy Delphi method through interviews with twenty two experts. After collecting the data and solving it by using the fuzzy Delphi method in three stages, the criteria in which the experts' disagreement at different stages was below the threshold of 0.2 and their mean score was more than 8 were finally chosen after collecting data by the fuzzy Delphi method. The screening results are summarized in Tab. 3 . 


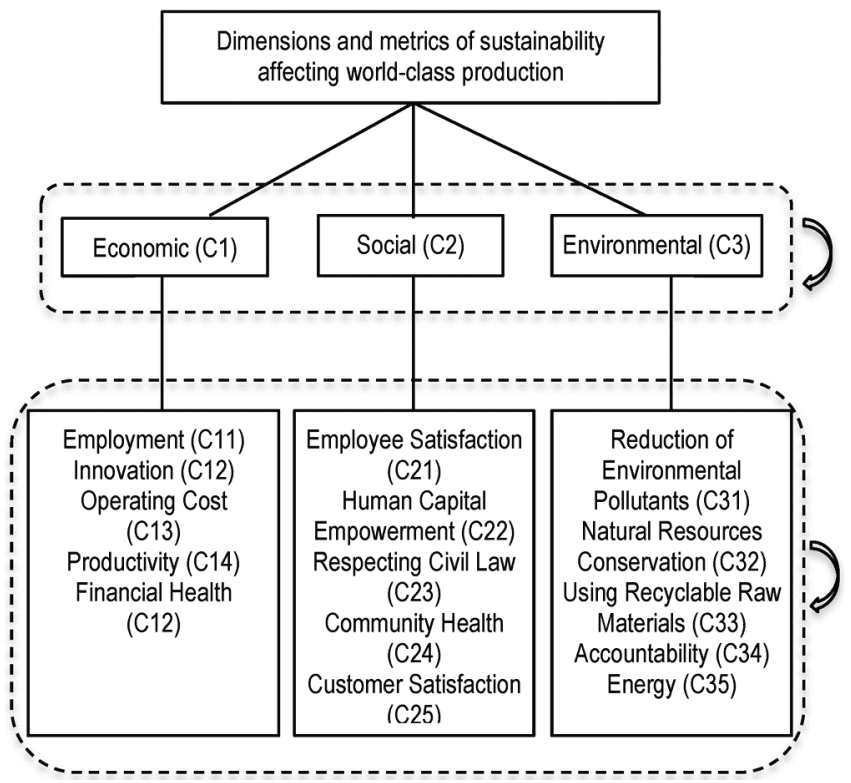

Figure 1 The model and network structure of the research on the sustainable WCM
Fig. 1 illustrates the network structure model of the dimensions and measures of sustainability affecting WCM. In this chart, the relationships between all dimensions and criteria are considered.

Since the second question of the research is what the relationships between the sustainability dimensions and criteria and their effects on each other in WCM are, the DEMATEL method was used to answer this question. To this end, nine experts from the automotive company measure responded to the impact of each sustainability dimension and criteria on the spectrum of very high impact (4), high impact (3), low impact (2), very low impact (1), and without impact (0). Therefore, a fuzzy direct relation matrix for sustainability dimensions (Tab. 4) and criteria (Tab. 5) was formed after collecting the data and aggregating the views by using the arithmetic mean.

Table 4 Fuzzy integrated direct relationship matrix of sustainability dimensions

\begin{tabular}{|c|c|c|c|c|c|c|c|c|c|}
\hline & \multicolumn{3}{|c|}{ Economical } & \multicolumn{3}{|c|}{ Social } & \multicolumn{3}{|c|}{ Environmental } \\
\hline & $\begin{array}{l}\text { Upper } \\
\text { bound }\end{array}$ & $\begin{array}{c}\text { Middle } \\
\text { bound }\end{array}$ & $\begin{array}{l}\text { Lower } \\
\text { bound }\end{array}$ & $\begin{array}{l}\text { Upper } \\
\text { bound }\end{array}$ & $\begin{array}{c}\text { Middle } \\
\text { bound }\end{array}$ & $\begin{array}{l}\text { Lower } \\
\text { bound }\end{array}$ & $\begin{array}{l}\text { Upper } \\
\text { bound }\end{array}$ & $\begin{array}{l}\text { Middle } \\
\text { bound }\end{array}$ & $\begin{array}{l}\text { Lower } \\
\text { bound }\end{array}$ \\
\hline Economical & \multicolumn{3}{|c|}{$(0,0,0)$} & \multicolumn{3}{|c|}{$(0 / 5,0 / 75,0 / 917)$} & \multicolumn{3}{|c|}{$\frac{1}{(0 / 714,0 / 667,0 / 917)}$} \\
\hline Social & \multirow{2}{*}{\multicolumn{3}{|c|}{$(0 / 5,0 / 75,0 / 917)$}} & \multicolumn{3}{|c|}{$(0,0,0)$} & \multicolumn{3}{|c|}{$(0 / 25,0 / 5,0 / 75)$} \\
\hline Environmental & & \multicolumn{2}{|c|}{$(0 / 417,0 / 667,0 / 917)$} & \multicolumn{3}{|c|}{$(0 / 333,0 / 583,0 / 833)$} & \multicolumn{3}{|c|}{$(0,0,0)$} \\
\hline
\end{tabular}

Table 5 Fuzzy integrated direct relationship matrix of the sustainability criteria

\begin{tabular}{|c|c|c|c|c|c|}
\hline $\mathrm{C}$ & $\mathrm{C}_{11}$ & $\mathrm{C}_{12}$ & $\mathrm{C}$ & $\mathrm{C}_{34}$ & $\mathrm{C}_{35}$ \\
\hline $\mathrm{C}_{11}$ & \multirow{5}{*}{$\begin{array}{c}(0,0,0) \\
(0 / 3,0 / 45,0 / 65) \\
(0 / 2,0 / 35,0 / 6) \\
(0 / 3,0 / 45,0 / 65) \\
(0 / 35,0 / 5,0 / 7)\end{array}$} & \multirow{5}{*}{$\begin{array}{c}(0 / 3,0 / 45,0 / 65) \\
(0,0,0) \\
(0 / 25,0 / 4,0 / 65) \\
(0 / 5,0 / 45,0 / 7) \\
(0 / 3,0 / 45,0 / 65) \\
\end{array}$} & $\cdots$ & \multirow{5}{*}{$\begin{array}{c}(0 / 25,0 / 4,0 / 6) \\
(0 / 25,0 / 4,0 / 65) \\
(0 / 1,0 / 2,0 / 45) \\
(0 / 2,0 / 35,0 / 6) \\
(0 / 2,0 / 3,0 / 65)\end{array}$} & \multirow{5}{*}{$\begin{array}{c}(0 / 25,0 / 4,0 / 65) \\
(0 / 35,0 / 5,0 / 7) \\
(0 / 2,0 / 35,0 / 6) \\
(0 / 35,0 / 5,0 / 7) \\
(0 / 2,0 / 3,0 / 5)\end{array}$} \\
\hline $\mathrm{C}_{12}$ & & & $\cdots$ & & \\
\hline $\mathrm{C}_{13}$ & & & $\ldots$ & & \\
\hline $\mathrm{C}_{14}$ & & & $\cdots$ & & \\
\hline $\mathrm{C}_{15}$ & & & $\cdots$ & & \\
\hline $\mathrm{C}_{21}$ & \multirow{5}{*}{$\begin{array}{c}(0 / 35,0 / 5,0 / 7) \\
(0 / 35,0 / 5,0 / 7) \\
(0 / 15,0 / 3,0 / 55) \\
(0 / 125,0 / 25,0 / 5) \\
(0 / 3,0 / 45,0 / 65)\end{array}$} & \multirow{5}{*}{$\begin{array}{c}(0 / 3,0 / 45,0 / 7) \\
(0 / 25,0 / 4,0 / 65) \\
(0 / 15,0 / 3,0 / 55) \\
(0 / 25,0 / 4,0 / 65) \\
(0 / 18,0 / 31,0 / 56)\end{array}$} & $\ldots$ & \multirow{5}{*}{$\begin{array}{c}(0 / 4,0 / 55,0 / 7) \\
(0 / 25,0 / 4,0 / 65) \\
(0 / 2,0 / 3,0 / 55) \\
(0 / 125,0 / 25,0 / 5) \\
(0 / 25,0 / 4,0 / 65)\end{array}$} & \multirow{5}{*}{$\begin{array}{c}(0 / 3,0 / 45,0 / 65) \\
(0 / 2,0 / 35,0 / 6) \\
(0 / 15,0 / 25,0 / 5) \\
(0 / 25,0 / 37,0 / 62) \\
(0 / 1,0 / 25,0 / 5) \\
\end{array}$} \\
\hline $\mathrm{C}_{22}$ & & & $\ldots$ & & \\
\hline $\mathrm{C}_{23}$ & & & $\cdots$ & & \\
\hline $\mathrm{C}_{24}$ & & & $\ldots$ & & \\
\hline $\mathrm{C}_{25}$ & & & $\cdots$ & & \\
\hline $\mathrm{C}_{31}$ & \multirow{5}{*}{$\begin{array}{c}(0 / 25,0 / 4,0 / 65) \\
(0 / 35,0 / 5,0 / 7) \\
(0 / 35,0 / 5,0 / 7) \\
(0 / 3,0 / 45,0 / 7) \\
(0 / 25,0 / 4,0 / 65)\end{array}$} & \multirow{5}{*}{$\begin{array}{c}(0 / 15,0 / 3,0 / 55) \\
(0 / 2,0 / 35,0 / 6) \\
(0 / 25,0 / 4,0 / 65) \\
(0 / 2,0 / 35,0 / 6) \\
(0 / 4,0 / 55,0 / 7)\end{array}$} & $\cdots$ & \multirow{5}{*}{$\begin{array}{c}(0 / 2,0 / 35,0 / 6) \\
(0 / 1,0 / 2,0 / 45) \\
(0 / 1,0 / 25,0 / 5) \\
(0,0,0) \\
(0 / 2,0 / 35,0 / 6) \\
\end{array}$} & \multirow{5}{*}{$\begin{array}{c}(0 / 3,0 / 45,0 / 7) \\
(0 / 25,0 / 4,0 / 65) \\
(0 / 25,0 / 4,0 / 65) \\
(0 / 2,0 / 3,0 / 5) \\
(0,0,0)\end{array}$} \\
\hline $\mathrm{C}_{32}$ & & & $\ldots$ & & \\
\hline $\mathrm{C}_{33}$ & & & $\ldots$ & & \\
\hline $\mathrm{C}_{34}$ & & & $\cdots$ & & \\
\hline $\mathrm{C}_{35}$ & & & $\cdots$ & & \\
\hline
\end{tabular}

Note: This matrix is compressed due to the large size of the matrix $15 \times 15$ and the lack of screen space.

Table 6 Matrix of fuzzy general relationships among the sustainability dimension

\begin{tabular}{|c|c|c|c|}
\hline & $\mathrm{C}_{1}$ & $\mathrm{C}_{2}$ & $\mathrm{C}_{3}$ \\
\hline $\mathrm{C}_{1}$ & $(0 / 17,0 / 73,7 / 29)$ & $(0 / 98,1,7 / 41)$ & $(0 / 32,0 / 91,7 / 18)$ \\
\hline $\mathrm{C}_{2}$ & $(0 / 37,0 / 97,7 / 17)$ & $(0 / 14,0 / 65,6 / 64)$ & $(0 / 24,0 / 80,6 / 72)$ \\
\hline $\mathrm{C}_{3}$ & $(0 / 33,0 / 73,7 / 41)$ & $(0 / 3,0 / 89,7 / 18)$ & $(0 / 17,0 / 89,6 / 64)$ \\
\hline
\end{tabular}

In the next step, the normalized matrix was calculated for the dimensions, and the criteria of sustainability affecting WCM and the fuzzy general relations matrix $(\widetilde{\boldsymbol{T}})$ were obtained by multiplying the normal matrix in the inverse matrix after subtracting the fuzzy direct relation matrix from the normal matrix and calculating the inverse matrix. Tab. 6 illustrates the general relations matrix for the dimensions and Tab. 7 illustrates the sustainability criteria affecting WCM.
Finally, to determine the relationships, the effect value $(\widetilde{D})$ is obtained from the sum of the rows, the impact of $(\tilde{R} t)$ is obtained from the sum of columns, the significance $(\widetilde{D}+$ $\widetilde{R})$ and the net fuzzy effect $(\widetilde{D}-\widetilde{R})$ on the dimensions and the criteria of sustainability affecting WCM that are given in Tab. 8.

Based on Tab. 8, the "environmental" dimension is the most effective one with the highest impact / impressiveness of 0.295 and the "social" dimension was the most impressive one with the least net impact / impressiveness of -0.293 . Among the environmental criteria, the criterion of the "reduction of environmental pollutants" is the most effective and the "protection of natural resources" is the most 
impressive criteria. Among the economic criteria, "innovation" has the most impact and the "operating cost" has the most impressiveness. Finally, among the social criteria, the criterion of "employee satisfaction" has the most impact and the criterion of "customer satisfaction" is the most impressive criteria in WCM.

Table 7 Matrix of fuzzy general relationships among the sustainability criteria
\begin{tabular}{|c|c|c|c|c|c|}
\hline $\mathrm{C}$ & $\mathrm{C}_{11}$ & $\mathrm{C}_{12}$ & $\mathrm{C}$ & $\mathrm{C}_{34}$ & $(0 / 041,0 / 1,0 / 98)$ \\
\hline $\mathrm{C}_{11}$ & $(0 / 021,0 / 07,1 / 04)$ & $(0 / 05,0 / 11,1 / 08)$ & $\cdots$ & $(0 / 041,0 / 1,1 / 10)$ & $(0 / 044,0 / 11,1 / 04)$ \\
\hline $\mathrm{C}_{12}$ & $(0 / 052,0 / 12,1 / 13)$ & $(0 / 019,0 / 07,1 / 04)$ & $\cdots$ & $(0 / 019,0 / 06,0 / 83)$ & $(0 / 031,0 / 08,0 / 89)$ \\
\hline $\mathrm{C}_{13}$ & $(0 / 033,0 / 09,0 / 95)$ & $(0 / 037,0 / 09,0 / 93)$ & $\cdots$ & $(0 / 034,0 / 09,0 / 96)$ & $(0 / 051,0 / 11,1 / 03)$ \\
\hline $\mathrm{C}_{14}$ & $(0 / 048,0 / 11,1 / 08)$ & $(0 / 047,0 / 11,1 / 07)$ & $\cdots$ & $(0 / 035,0 / 08,0 / 9)$ & $(0 / 037,0 / 09,0 / 96)$ \\
\hline $\mathrm{C}_{15}$ & $(0 / 055,0 / 12,1 / 03)$ & $(0 / 049,0 / 11,1 / 01)$ & $\cdots$ & $(0 / 058,0 / 12,1 / 02)$ & $(0 / 05,0 / 11,1 / 07)$ \\
\hline $\mathrm{C}_{21}$ & $(0 / 059,0 / 13,1 / 14)$ & $(0 / 057,0 / 12,1 / 12)$ & $\cdots$ & $(0 / 039,0 / 09,0 / 97)$ & $(0 / 036,0 / 09,1 / 02)$ \\
\hline $\mathrm{C}_{22}$ & $(0 / 054,0 / 12,1 / 09)$ & $(0 / 042,0 / 1,1 / 06)$ & $\cdots$ & $(0 / 034,0 / 08,0 / 94)$ & $(0 / 031,0 / 08,0 / 99)$ \\
\hline $\mathrm{C}_{23}$ & $(0 / 034,0 / 1,1 / 06)$ & $(0 / 032,0 / 09,1 / 03)$ & $\cdots$ & $(0 / 025,0 / 08,0 / 91)$ & $(0 / 04,0 / 09,0 / 98)$ \\
\hline $\mathrm{C}_{24}$ & $(0 / 03,0 / 09,1 / 02)$ & $(0 / 041,0 / 1,1 / 01)$ & $\cdots$ & $(0 / 038,0 / 09,0 / 93)$ & $(0 / 024,0 / 08,0 / 97)$ \\
\hline $\mathrm{C}_{25}$ & $(0 / 047,0 / 11,1 / 04)$ & $(0 / 034,0 / 09,1 / 01)$ & $\cdots$ & $(0 / 035,0 / 09,0 / 99)$ & $(0 / 048,0 / 11,1 / 05)$ \\
\hline $\mathrm{C}_{31}$ & $(0 / 045,0 / 11,1 / 11)$ & $(0 / 034,0 / 1,1 / 08)$ & $\cdots$ & $(0 / 024,0 / 07,0 / 95)$ & $(0 / 042,0 / 1,1 / 02)$ \\
\hline $\mathrm{C}_{32}$ & $(0 / 055,0 / 12,1 / 09)$ & $(0 / 038,1 / 0,1 / 05)$ & $\cdots$ & $(0 / 025,0 / 08,0 / 97)$ & $(0 / 043,0 / 1,1 / 04)$ \\
\hline $\mathrm{C}_{33}$ & $(0 / 056,0 / 12,1 / 11)$ & $(0 / 044,0 / 11,1 / 08)$ & $\cdots$ & $(0 / 013,0 / 05,0 / 89)$ & $(0 / 036,0 / 09,0 / 99)$ \\
\hline $\mathrm{C}_{34}$ & $(0 / 049,0 / 11,1 / 07)$ & $(0 / 037,0 / 1,1 / 04)$ & $\cdots$ & $(0 / 035,0 / 09,0 / 99)$ & $(0 / 016,0 / 06,0 / 98)$ \\
\hline $\mathrm{C}_{35}$ & $(0 / 045,0 / 11,1 / 11)$ & $(0 / 058,0 / 12,1 / 09)$ & $\cdots$ & & \\
\hline
\end{tabular}

Note: This matrix is compressed due to the large size of the matrix $15 \times 15$ and the lack of screen space.

Table 8 Interaction and order of the impact /impressiveness value of effective sustainability dimensions and the criteria on WCM

\begin{tabular}{|c|c|c|c|c|c|c|c|}
\hline $\begin{array}{l}\text { Sustainability } \\
\text { dimension }\end{array}$ & $\begin{array}{l}\text { Interaction } \\
\text { values }\end{array}$ & $\begin{array}{l}\text { The order of net } \\
\text { impact / } \\
\text { impressiveness }\end{array}$ & Result & Sustainability criteria & $\begin{array}{l}\text { Interaction } \\
\text { values }\end{array}$ & $\begin{array}{c}\text { The order of net impact } \\
\text { / impressiveness }\end{array}$ & Result \\
\hline \multirow{5}{*}{ Biological } & \multirow{5}{*}{$15 / 96$} & \multirow{5}{*}{$0 / 295$} & \multirow{5}{*}{ Effective } & Reducing environmental pollutants & $3 / 767$ & $0 / 086$ & \multirow{3}{*}{ Effective } \\
\hline & & & & Responsiveness & $3 / 581$ & $0 / 045$ & \\
\hline & & & & Using recyclable raw materials & $3 / 778$ & $0 / 006$ & \\
\hline & & & & Energy & $3 / 819$ & $-0 / 0062$ & \multirow[b]{2}{*}{ Impressive } \\
\hline & & & & Conservation of natural resources & $3 / 809$ & $-0 / 131$ & \\
\hline \multirow{5}{*}{ Economical } & \multirow{5}{*}{$16 / 93$} & \multirow{5}{*}{$-0 / 002$} & \multirow{10}{*}{ Impressive } & Innovation & $4 / 047$ & $0 / 174$ & \multirow{3}{*}{ Effective } \\
\hline & & & & Employment & $4 / 055$ & $0 / 091$ & \\
\hline & & & & Efficiency & $3 / 999$ & $0 / 02$ & \\
\hline & & & & Financial health & $3 / 931$ & $-0 / 043$ & \multirow{2}{*}{ Impressive } \\
\hline & & & & Operational cost & $3 / 744$ & $-0 / 242$ & \\
\hline \multirow{5}{*}{ Social } & \multirow{5}{*}{$16 / 1$} & \multirow{5}{*}{$-0 / 293$} & & Employee satisfaction & $4 / 046$ & $0 / 184$ & \multirow{2}{*}{ Effective } \\
\hline & & & & Respecting civil laws and regulations & $3 / 86$ & $0 / 053$ & \\
\hline & & & & Community health & $3 / 812$ & $-0 / 015$ & \multirow{3}{*}{ Impressive } \\
\hline & & & & Empowering human capital & $4 / 027$ & $-0 / 08$ & \\
\hline & & & & Customer satisfaction & $3 / 917$ & $-0 / 142$ & \\
\hline
\end{tabular}

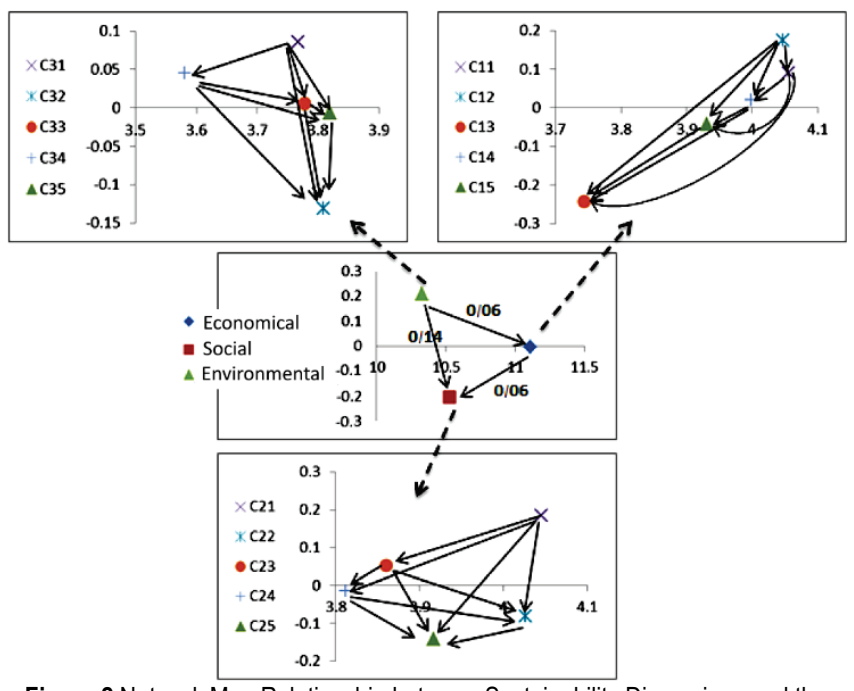

Figure 2 Network Map Relationship between Sustainability Dimensions and the Criteria Affecting WCM [2]

Finally, the fuzzy general relations matrix is used to delineate the Network Relations Map (NRM). Fig. 2 illustrates the NRM for the dimensions and the criteria of sustainability affecting WCM, in which the interactions and the direction of impact between the dimensions and criteria are specified. As Fig. 2 shows, the "environmental" dimension affects $6 \%$ on the "economic" dimension and $14 \%$ on the "social" dimension. This result indicates that the impressive dimensions are improved to the percentages specified by a one percent increase in the "environmental" dimension. Additionally, the "economic" dimension affects the "social" dimension by $6 \%$. Based on this result, the "social" dimension improves by $6 \%$ through increasing one percent of the "economic" dimension.

Based on Fig. 2, the social dimension is the most influential one that needs to be improved for WCM. Based on this result, governments and organizations can achieve WCM through improving social indicators. Managers and policy makers at the strategic level can focus on the environmental dimension (which is most effective) to improve the "social" dimension and improve the social dimension through the "environmental" and "economic" dimensions. At the operational level, managers also focus on 
the social criteria. To this end, it is necessary to improve "customer satisfaction" (most effective) through "employee satisfaction" (most effective). "Operating costs" and "financial health" should be improved through the "innovation" criteria to improve the "economic" dimension; because according to the relationship network map, the criteria of the "operating cost" and "financial health" are the most impressive and the "innovation" criteria are the most effective criteria.

More attention needs to be paid to the "conserve natural resources" criterion in order to meet the "environmental" criteria in WCM, since environmental dimension was the most impressive. In other words, environmental success depends on the "conservation of nature" criterion, which is improved by "reducing environmental pollutants". Therefore, managers can focus on the criterion of "reducing environmental pollutants" to achieve and improve the "conservation of natural resources".

Table 9 Weight and Importance of Dimensions and Criteria for Sustainability Affecting WCM

\begin{tabular}{|c|c|c|c|c|}
\hline \multicolumn{2}{|c|}{$\begin{array}{l}\text { Dimensions of } \\
\text { sustainability }\end{array}$} & \multirow{2}{*}{$\begin{array}{c}\begin{array}{c}\text { Sustainability } \\
\text { Criteria }\end{array} \\
\text { Employment } \\
\end{array}$} & \multirow{2}{*}{$\begin{array}{l}\text { Weight and the } \\
\text { relative } \\
\text { importance of } \\
\text { sub-factors } \\
\text { (4) } 0 / 199\end{array}$} & \multirow{2}{*}{$\begin{array}{c}\begin{array}{c}\text { The final } \\
\text { weight and } \\
\text { importance of } \\
\text { sub-factors }\end{array} \\
\text { (6) } 0 / 0709 \\
\end{array}$} \\
\hline \multirow{5}{*}{  } & \multirow{5}{*}{$\begin{array}{l}\stackrel{\circ}{n} \\
\stackrel{n}{\delta} \\
ٍ\end{array}$} & & & \\
\hline & & Innovation & (5) $0 / 187$ & (7) $0 / 0667$ \\
\hline & & Operational cost & (1) $0 / 208$ & (1) $0 / 0741$ \\
\hline & & Efficiency & (3) $0 / 2$ & (5) $0 / 0713$ \\
\hline & & Financial health & (2) $0 / 205$ & (2) $0 / 0732$ \\
\hline \multirow{5}{*}{$\begin{array}{l}\overline{\frac{\pi}{2}} \\
0 \\
0\end{array}$} & \multirow{5}{*}{$\begin{array}{l}\hat{m} \\
\stackrel{0}{\delta}\end{array}$} & $\begin{array}{c}\text { Employee } \\
\text { satisfaction }\end{array}$ & (3) $0 / 196$ & (8) $0 / 0661$ \\
\hline & & $\begin{array}{c}\text { Empowering } \\
\text { Human capital }\end{array}$ & (1) $0 / 214$ & (3) $0 / 0723$ \\
\hline & & $\begin{array}{l}\text { Respecting civil } \\
\text { laws and } \\
\text { regulations }\end{array}$ & (5) $0 / 185$ & (12) $0 / 0626$ \\
\hline & & Community health & (4) $0 / 192$ & (10) $0 / 0649$ \\
\hline & & $\begin{array}{l}\text { Customer } \\
\text { satisfaction }\end{array}$ & (2) $0 / 212$ & (4) $0 / 0714)$ \\
\hline \multirow{5}{*}{ 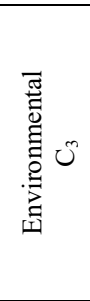 } & \multirow{5}{*}{ 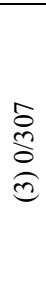 } & $\begin{array}{c}\text { Reducing } \\
\text { environmental } \\
\text { pollutants }\end{array}$ & (4) $0 / 193$ & (14) $0 / 059$ \\
\hline & & $\begin{array}{c}\text { Conservation of } \\
\text { natural resources }\end{array}$ & (1) $0 / 212$ & (9) $0 / 065$ \\
\hline & & $\begin{array}{l}\text { Using recyclable } \\
\text { raw materials }\end{array}$ & (3) $0 / 198$ & (13) $0 / 0608$ \\
\hline & & Responsiveness & (5) $0 / 188$ & (15) $0 / 0578$ \\
\hline & & Energy & (2) $0 / 208$ & (11) $0 / 0639$ \\
\hline
\end{tabular}

Hence, to obtain the importance of each dimension and the criteria of sustainability affecting WCM, the fuzzy ANP method was used to calculate the weight to determine the significance. In this study, the fuzzy ANP [45] is solved based on the general relations matrix in the fuzzy DEMATEL method. In this section, the DEMATEL general relations matrix was first normalized and the balanced fuzzy super matrix was obtained. The balanced super matrix is converged through the equation $\lim _{K \rightarrow \infty}\left(W^{\alpha}\right)^{K}$ in the power of 9-5 digits and the limit matrix was formed. Finally, the weight of the dimensions and the criteria of sustainability affecting the WCL were identified and the degree of significance was obtained through obtaining the boundary super matrix and its defuzzification by the gravity center method (Tab. 9).

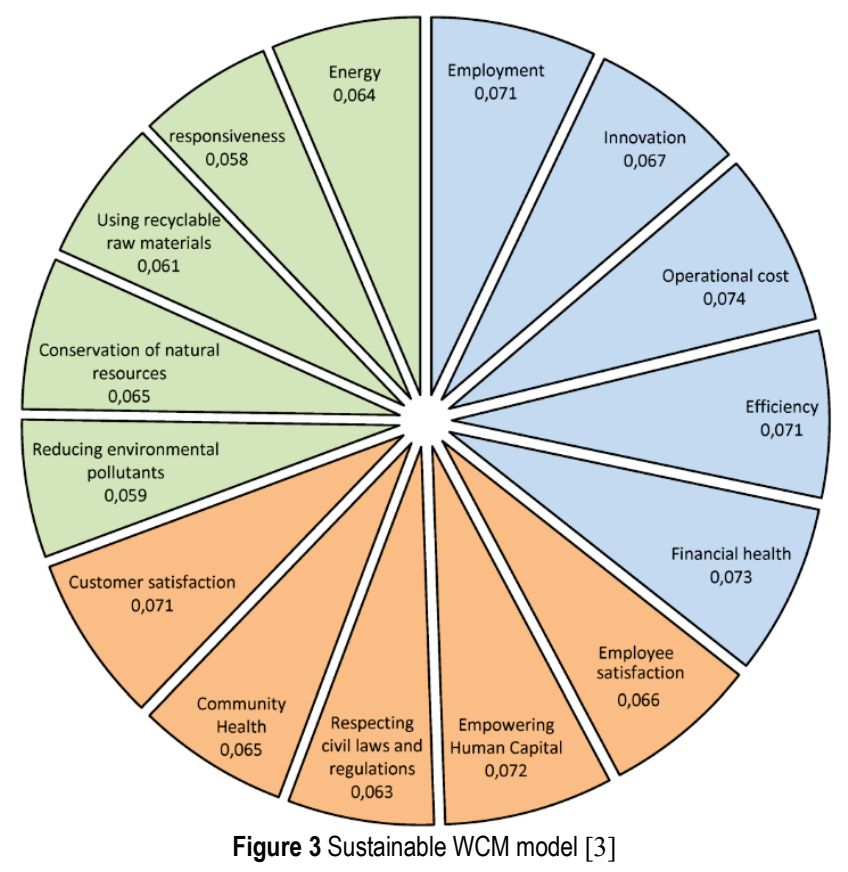

As Tab. 9 illustrates, the majority of the weight is related to the "economic" dimension that has the most impact on WCM. The "operating cost" criterion with the highest relative weight of 0.220 has the greatest impact on the sustainable WCM. "Empowering human capital" in the social dimension of 0.221 has the most significance in achieving the sustainable WCM. The conservation of natural resources, with a weight of 0.221 , is one of the top priorities in the environmental dimension for achieving the sustainable WCM. Based on the results in Tab. 9, Fig. 3 illustrates the sustainable WCM model.

\section{CONCLUSION AND RECOMMENDATIONS}

Today, governments, international organizations, and support groups have made great efforts to enable human societies to sustainably do business due to lack of resources and environmental protection. The present study aimed to design a sustainable WCM model in which the dimensions and criteria of sustainability were selected by the fuzzy Delphi method and then, its importance was determined in the model by the fuzzy DANP method. In this model, managers can focus on designated relationships and impact / impressiveness for improvement.

According to the research findings, the "economic" dimension at the strategic level is of the utmost importance and has the most impact on the sustainable WCM. This result indicates that managers and policymakers should focus more on the "economic" dimension of achieving the sustainable WCM. If the organization improves its economic benchmarks, the sustainable WCM is expected to improve. Based on the results, it is necessary to plan on the "environmental" dimension (most influential) and it should be a part of the improvement priorities and attention should 
be paid to how it is communicated in order to improve the economic dimension. Moreover, analyzing the relationships between the economic criteria can improve this criterion. Accordingly, the "operating costs" and "financial health" criteria are improved through the "innovation" criteria. It is therefore recommended that managers create guidelines for innovation in the automotive industry and prepare the environment and context for it.

The "operating cost" criterion has the most impact on the sustainable WCM at the operational level. This result indicates that high reliability, responsive, flexible production and the production based on customer needs can be achieved through controlling and reducing operating costs such as waste, duplications, breakdowns, energy and other costs. For example, an organization can reduce waste, mistakes, and duplications by increasing staff skills, software programs, and statistical quality control. Therefore, it is recommended that the organization identifies operational costs that lead to the waste of resources, and that they take measures to control and reduce it.

The "financial health" criterion is the second priority in achieving the sustainable WCM in terms of importance. This result indicates that the criterion of "financial health" is also one of the most important cases in the sustainable WCM. Financial health is the ability to add the value of the capability and the continuity of business activities in organizations and can prevent bankruptcy, because the performance of business units can be analyzed and evaluated through financial reports and financial ratios analyses. Therefore, managers can identify their weaknesses and strengths by presenting historical financial reports and they can achieve sustainable production by creating improvement plans. Furthermore, the "operating cost" and "financial health" criteria have the most impact on the economic dimension, focusing on the most effective and the most efficient factor (innovation) to improve and control their effectiveness in order to prevent failure. Decision makers are recommended to improve "operating costs" and "financial health" through innovations in economic activities, including the use of new and innovative methods and tools such as artificial intelligence tools and production methods.

The "Human Capital Empowerment Criterion" is the third priority of the sustainable WCM model. It is considered that human resources that can help organizations succeed in producing the sustainable WCM are the most valuable asset of an organization. Therefore, one of the most effective ways to achieve the sustainable WCM is expected to be human resource development and empowerment. It is suggested that managers achieve quality production, competitive prices, appropriate after-sales service, and WCM delivery by developing and empowering human resources through improved skills, knowledge and motivation. Based on the identified relationships, the human capital empowerment leads to customer satisfaction and influences it. Since the present study was conducted at a state-owned automobile company with specific features and structure, it is expected that the findings of the present study would not be generalizable to other similar companies and other industries; therefore, it is recommended that researchers conduct the present research in other organizations in order to realize its comprehensiveness.

\section{REFERENCES}

[1] Caldera, H. T. S., Desha, C., \& Dawes, L. (2019) Transforming manufacturing to be 'good for planet and people', through enabling lean and green thinking in small and medium-sized enterprises. https://doi.org/10.1186/s42055-019-0011-z

[2] Darabpour, M., Darabpour, M., Majrouhi Sardroud, J., Smallwood, J., \& Tabarsa, G. (2018). Practical Approaches Toward Sustainable Development in Iranian Green Construction. Civil Engineering Journal, 4. 2450. https://doi.org/10.28991/cej-03091172

[3] Kristensen, N. P., Chisholm, R. A., \& McDonald-Madden, E. (2019). Dealing with high uncertainty in qualitative network models. https://doi.org/10.1111/2041-210X.13179

[4] Bocken, N., Strupeit, L., Whalen, K., \& Nußholz, J. (2019). A review and evaluation of circular business model innovation tools. Sustainability 2019, 11, 2210. https://doi.org/10.3390/su11082210

[5] Mirhabibi, S. D., Farsijani, H., Modiri, M., \& Damghani, K. K. (2018). Explaining the Role of Integrated Supply Chain on Attainment of World Class Manufacturing in Electronic Domestic Appliance Industries. https://doi.org/10.22059/imj.2018.247134.1007355

[6] Sohrab, K. S., Hossain, S., Nazemi, J., \& Alborzi, M. (2016). Operations strategy and business strategy alignment model (case of Iranian industries). International Journal of Operations \& Production. https://doi.org/10.1108/IJOPM-12-2011-0467

[7] Petrillo, A., De Felice, F., \& Zomparelli, F. (2019). Performance measurement for world-class manufacturing a model for the Italian automotive industry. https://doi.org/10.1080/14783363.2017.1408402

[8] Sukarma, L. (2014). The Impact of World Class Manufacturing Practices on Company Performance. Applied Mechanics and Materials, 761. https://doi.org/10.4028/www.scientific.net/AMM.564.727

[9] Moultrie, J. \& Corsini, L. (2019). Design for Social Sustainability: Using Digital Fabrication in the Humanitarian and Development Sector. Sustainability, 11(13), 3562. https://doi.org/10.3390/su11133562

[10] Habidin, N., Hashim, S., Zainol, Z., Wan, M., Ong, S., \& Hudin, N. S. (2015). Measuring the innovation performance of Malaysian automotive industry. Geografia: International Journal of Development, Society and Environment, 11, 14-23.

[11] Morunova, G., Gorbushina, S., Okrepilov, V., \& Kuzmina, S. (2018). Sustainable development of municipalities: financial assurance infrastructure. E3S Web of Conferences. 110. 02060. https://doi.org/10.1051/e3sconf/201911002060

[12] Yacob, P., Wong, L. S., \& Khor, S. C. (2019). An Empirical Investigation of Green.Initiatives and Environmental Sustainability for Manufacturing SMEs. Journal of Manufacturing Technology Management. https://www.researchgate.net/publication/325263470

[13] Urfalı Doğu, F. \& Aras, L. (2019). Measuring Social Sustainability with the Developed MCSA Model: Güzelyurt Case. Sustainability, 11(9), 2503. https://doi.org/10.3390/su11092503

[14] Boyer, R. H. W., Peterson, N. D., Arora, P., \& Caldwell, K. (2016). Five Approaches to Social Sustainability and an Integrated Way Forward. Sustainability, 8(9), 878. https://doi.org/10.3390/su8090878

[15] Ewert, F., Rötter, R. P., Bindi, M., Webber, H., Trnka, M., Kersebaum, K. C. ... Semenov, M. A. (2015). Crop modelling for integrated assessment of risk to food production from 
climate change. Environmental Modelling \& Software, 72, 287-303. https://doi.org/10.1016/j.envsoft.2014.12.003

[16] Furlan, A. \& Vinelli A. (2018). Unpacking the coexistence between improvement and innovation in world-class manufacturing: A dynamic capability approach. Technological Forecasting and Social Change, 133, 168-178. https://doi.org/10.1016/j.techfore.2018.03.022

[17] Ocampo, L. \& Clark, E. E. (2014). A framework for capturing uncertainty of group decision-making in the context of the analytic hierarchy/network process. Advances in Industrial Engineering and Management, 3, 7-16. https://doi.org/10.7508/AlEM-V3-N3-7-16

[18] Hu, S.-K., Liou, J., Lu, M.-T., Chuang, Y.-C., \& Tzeng, G.-H. (2018). Improving NFC Technology Promotion for Creating the Sustainable Education Environment by Using a Hybrid Modified MADM Model. Sustainability, 10(5), 1379. https://doi.org/10.3390/su10051379

[19] Qi, X. (2018). Social Capital. In book: The Wiley-Blackwell Encyclopedia of Social Theory, Publisher: London: Wiley Blackwell, Editors: B Turner et al., 2125-2127.

[20] Atkinson, G., Dietz, S., Neumayer, E., \& Agarwala, M. (2014). Handbook of Sustainable Development, Second Edition, Edward Elgar Publishing: Cheltenham, UK. https://doi.org/10.4337/9781782544708

[21] Abel, T. (2015). Gentrified sustainability: Inequitable development and Seattle's skewed riskscape. Interdisciplinary Environmental Review (IER), 16, 124. https://doi.org/10.1504/IER.2015.071014

[22] Shove, E., Pantzar, M., \& Watson, M. (2012). The Dynamics of Social Practice: Everyday Life and How It Changes; SAGE Publications: Thousand Oaks, CA, USA. https://doi.org/10.4135/9781446250655

[23] Chiarini, A. \& Vagnoni, E. (2015). World-Class Manufacturing by Fiat. Comparison with Toyota Production System from A Strategic Management, Management Accounting, Operations Management and Performance Measurement Dimension. International Journal of Production Research, 53(2), 590-606. https://doi.org/10.1080/00207543.2014.958596

[24] De Felice, F., Petrillo, A., \& Monfreda, S. (2013). Improving Operations Performance with World Class Manufacturing Technique: A Case in Automotive Industry. London: INTECH Open Access Publisher. https://doi.org/10.5772/54450

[25] FCA (2019). World Class Manufacturing Audit System in Fiat Chrysler Automotive. https://www.wcm.fcagroup.com/ enus/development_center/Pages/audit_system.aspx.

[26] Jain, B., Adil G. K., \& Ananthakumar, U. (2013). An instrument to measure factors of strategic manufacturing effectiveness based on Hayes and Wheelwright's model. Journal of Manufacturing Technology Management, 24(6), 812-829. https://doi.org/10.1108/JMTM-11-2011-0102

[27] Kucerova, M., Mlkva, M., \& Paulova, I. (2010). Applying principle of customer focus in busuness practice. Annals of $D A A A M$ \& Proceedings, 695. https://doi.org/10.2507/27th.daaam.proceedings

[28] Yoo, C. \& Lee, S. (2016). Neighborhood built environments affecting social capital and social sustainability in Seoul, Korea. Sustainability, 8(12), 1346. https://doi.org/10.3390/su8121346

[29] Vargas-Hernández, J. G. (2017). Strategies for organizational intervention to develop a world -class company.

[30] Kireitseu, M. (2017). Environmental Strategies for Sustainable Manufacturing Process of Composites.

https://doi.org/10.1088/1757-899X/229/1/012007
[31] Chiarini, A. \& Vagnoni, E. (2015). World-class manufacturing by fiat.comparison with Toyota production system from strategic management, management. https://doi.org/10.1080/00207543.2014.958596

[32] Dubey, R., Gunasekaran, A., Childe, S. J. et al. (2016). The impact of big data on world-class sustainable manufacturing. Int J Adv Manuf Technol, 84, 631-645. https://doi.org/10.1007/s00170-015-7674-1

[33] Dubey, R., Gunasekaran, A., Papadopoulos, T., Childe, S. J., Shibin, K. T., \& Fosso Wamba, S. (2017). Sustainable supply chain management: framework and further research directions. Journal of Cleaner Production, 142(2), 1119-1130. https://doi.org/10.1016/j.jclepro.2016.03.117

[34] Charan, P., Shankar, R., \& Baisya, R. K. (2008). Analysis of interactions among the variables of supply chain performance measurement system implementation. Business Process Management Journal, 14(4), 512-529. https://doi.org/10.1108/14637150810888055

[35] Joung, C. B., Carrell, J., Sarkar, P., \& Feng, S. C. (2013). Categorization of indicators for sustainable manufacturing. Ecological Indicators, 24, 148-157.

https://doi.org/10.1016/j.ecolind.2012.05.030

[36] Faisal, M. N., Banwet, D. K., \& Shankar, R. (2007). Quantification of Risk Mitigation Environment of Supply Chains Using Graph Theory and Matrix Methods. European J. Industrial Engineering, 1(1), 29-39. https://doi.org/10.1504/EJIE.2007.012652

[37] Radfar, R. T., Pilevari, N., \& Aflaki, S. (2011). A model for evaluating and comparing the agility of supply chain case study: Iran telecommunication company and Irancell company. American Journal of Scientific Research, 33, 127-135.

[38] Swafford, P. M., Ghosh, S., \& Nagesh, M. (2008). Achieving supply chain agility through IT integration and flexibility; International Journal of Production Economics, 116, 3465137. https://doi.org/10.1016/j.ijpe.2008.09.002

[39] Seyed-Hosseini, M., Elahi, B., \& Makui, A. (2011). Proposing a Mathematical Programming Model for Optimization of Supply Chain Scheduling. European Journal of Operational Research, 205, 469-478.

[40] Adeleye, E. O. \& Yusuf, Y. Y. (2006). Towards agile manufacturing: Models of competition and performance outcomes. International Journal Systems and Management. 1(1), 93-110. https://doi.org/10.1504/IJASM.2006.008861

[41] Agarwal, A., Shankar, R., \& Tiwari, M. K. (2006). Modeling the metrics of lean, agile and leagile supply chain: An ANPbased approach. European Journal of Operation Research, 173(1), 211-225. https://doi.org/10.1016/j.ejor.2004.12.005

[42] Baker, P. (2008). The design and operation of distribution centres within agile supply chain. International Journal of Production Economics, 111(1), 27-41. https://doi.org/10.1016/j.jpe.2006.09.019

[43] Berry, B. A. (2012). The path of excellence: World class leadership, Online Free .pdf Edition, 50-65.

[44] Thakkar, J., Kanda, A., \& Deshmukh, S. G. (2008). Evaluation of buyer supplier relationships using an integrated mathematical approach of interpretive structural modeling (ISM) and graph theoretic matrix: The case study of Indian automotive SMEs. Journal of Manufacturing Technology Management, 19(1), 92-124. https://doi.org/10.1108/17410380810843471

[45] Alvandi, M., Fazli, S., \& Memarzade, M. (2011). E-Supplier selection using Delphi, fuzzy AHP and SIR. European Journal of Scientific Research, 66(4), 481-509.

[46] Ocampo, L., Clark, E., \& Tanudtanud, K. V. (2015). A Sustainable Manufacturing Strategy from Different Strategic 
Responses under Uncertainty. Journal of Industrial Engineering, Volume 2015, Article ID 210568, 11 pages. https://doi.org/10.1155/2015/210568

[47] Despeisse, M., Ball, P. D., Evans, S., \& Levers, A. (2012). Industrialecology at factory level-a conceptual model. Journal of Cleaner Production, 31, 30-39. https://doi.org/10.1016/j.jclepro.2012.02.027

[48] Haleem, A., Sushil, Qadri, M. A., \& Kumar, S. (2012). Analysis of critical success factors of world-class manufacturing practices: an application of interpretative structural modelling and interpretative ranking process. Production Planning \& Control, 23(10-11), 722-734. https://doi.org/10.1080/09537287.2011.642134

[49] Kumar Yadav, P. \& Dixit, G. (2019). Investigation of erosioncorrosion of aluminium alloy composites: Influence of slurry composition and speed in a different mediums. Journal of King Saud University - Science, 31(4), 674-683. https://doi.org/10.1016/j.jksus.2019.02.003

[50] Mavi, R. K. \& Standing, C. (2018). Critical success factors of sustainable project management in construction: A fuzzy DEMATEL-ANP approach. Journal of Cleaner Production, 194, 751-765. https://doi.org/10.1016/j.jclepro.2018.05.120

[51] Cheng, C.-H. \& Yin, L. (2002). Evaluating the best mail battle tank using fuzzy decision theory with linguistic criteria evaluation. European Journal of Operational Research, 142(1), 147-186. https://doi.org/10.1016/S0377-2217(01)00280-6

[52] Awan, M. A. \& Ali, Y. (2019). Sustainable modeling in reverse logistics strategies using fuzzy MCDM: Case of China Pakistan Economic Corridor. Management of Environmental Quality, 30(5). https://doi.org/10.1108/MEQ-01-2019-0024

[53] Bilgin Sarı, E. (2019). World class manufacturing model and operational performance indicators. Comprision between WCM firms. Dokuz Eylül Üniversitesi Işsletme Fakültesi Dergisi, 19(2) , 249-269. https://doi.org/10.24889/ifede.404806

[54] Stankevičiūtè, Z. \& Savanevicien, A. (2018). Designing Sustainable HRM: The Core Characteristics of Emerging Field. Sustainability, 10(12), 4798. https://doi.org/10.3390/su10124798

\section{Authors' contacts:}

Zahra Pourvaziry, PhD (Corresponding author)

Department of Management, South Tehran Branch, Islamic Azad University, No. 223, Headquarter of Islamic Azad University, South Tehran Branch,

ZIP area 11, Azarshahr Street, North Iranshahr Street, Karimkhan-e-Zand Avenue, 1584743311 Tehran, Iran

E-mail: saye_sokoot7@icloud.com

Gholamreza Hashemzadeh Khorasgani, Associate Professor Department of Management, South Tehran Branch, Islamic Azad University, No. 223, Headquarter of Islamic Azad University, South Tehran Branch, ZIP area 11, Azarshahr Street, North Iranshahr Street, Karimkhan-e-Zand Avenue, 1584743311 Tehran, Iran

E-mail: hashemzadeh_gh@yahoo.com

Mahmud Modiri, Assistant Professor

Department of Management, South Tehran Branch, Islamic Azad University,

No. 223, Headquarter of Islamic Azad University, South Tehran Branch,

ZIP area 11, Azarshahr Street, North Iranshahr Street, Karimkhan-e-Zand Avenue, 1584743311 Tehran, Iran

E-mail: m_modiri@azad.ac.ir

Hassan Farsijani, Associate Professor

Department of Management, Shahid Beheshti University,

Shahid Beheshti University, Shahid Shahriari Square, Daneshjou Boulevard,

Shahid Chamran Highway, 1983969411 Tehran, Iran

E-Mail: h-farsi@sbu.ac.ir 